\title{
Reactivity in the Radical Copolymerization of Poly(2-oxazoline) Macromonomers with Methacrylate Monomers
}

\author{
Yasuo Shimano, ${ }^{\dagger}$ Kumiko Sato, Daisuke Fukui, \\ Yoshimitsu OnODERA, and Yoh Kimura \\ Department of Chemical and Biological Engineering, Hachinohe National College of Technology, \\ Tamonoki, Hachinohe 039-1192, Japan
}

(Received October 2, 1998)

\begin{abstract}
The radical copolymerization of vinylbenzyl-terminated poly(2-methyl-2-oxazoline) macromonomers (1 Me- $n$; $n$ (degree of polymerization $)=3,15,28,31)\left(\mathrm{M}_{1}\right)$ with vinyl monomers $\left(\mathrm{M}_{2}\right)$, i.e., methyl methacrylate (MMA) and 2-hydroxyethyl methacrylate (HEMA) was performed using 2, 2'-azobis(isobutyronitrile) (AIBN) as an initiator at $60^{\circ} \mathrm{C}$ in ethanol $(\mathrm{EtOH}), \mathrm{CD}_{3} \mathrm{OD}$, or $\mathrm{CD}_{3} \mathrm{CN}$. Monomer reactivity ratios $r_{1}$ and $r_{2}$ were evaluated based on the terminal model. Copolymerization of $1 \mathrm{Me}-3$ with MMA gave reactivity ratios as $r_{1}=1.86 \pm 0.15$ and $r_{2}=0.07 \pm 0.03$ in $\mathrm{EtOH}$, and $r_{1}=1.25 \pm 0.10$ and $r_{2}=0.18 \pm 0.05$ in $\mathrm{CD}_{3} \mathrm{OD}$, exhibiting remarkably higher reactivity of the Me- 3 compared with the comonomers and corresponding small monomer, styrene. In $\mathrm{CD}_{3} \mathrm{CN}$, however, copolymerization of $1 \mathrm{Me}-3$ with MMA gave $r_{1}=0.41 \pm 0.10$ and $r_{2}=0.66 \pm 0.10$, showing rather lower reactivity of the macromonomer compared with MMA. With HEMA, 1 Me-3 showed high reactivity in EtOH, i.e., $r_{1}=1.44 \pm 0.10, r_{2}=0.04 \pm 0.02$. The reactivity of HEMA against the macromonomers was found higher than that of MMA, possibly due to affinity to aprotic poly(2-methyl-2-oxazoline) graft chains on growing species. The high reactivity of $1 \mathrm{Me}-n$ in $\mathrm{EtOH}$ and $\mathrm{CD}_{3} \mathrm{OD}$ would be due to the formation of a micelle-like state. The reactivity of macromonomers decreased generally with chain length $(n)$.

KEY WORDS Macromonomers / Polyoxazoline / Radical Copolymerization / Monomer Reactivity Ratio / Methyl Methacrylate / 2-Hydroxyethyl Methacrylate
\end{abstract}

Poly(2-alkyl-2-oxazoline)s (PROZO) having the poly$(\mathrm{N}$-acylethylenimine) structure given by cationic ringopening polymerization of 2-alkyl-2-oxazoline (ROZO), can be regarded as a polymer homologue of polar aprotic solvents such as $N, N$-dimethylacet-amide, showing hydrophilic $(\mathrm{R}=\mathrm{Me}, \mathrm{Et})$ or hydrophobic (carbon number of $\mathrm{R} \geq 4$ ) properties. ${ }^{1}$ Monodisperse macromonomers of PROZO, e.g., styryl-, ${ }^{2}$ methacryloyl- ${ }^{3}$ and vinylester-terminated ${ }^{4}$ macromonomers, have been synthesized using living polymerization of ROZO. Longer alkyl groups ( R) in PROZO chain make macromonomers with regularly branched structure.

In general, homopolymerization of macromonomers produces star-like or comb-like polymers, while copolymerization with ordinary vinyl monomers forms graft copolymers. In particular, the synthesis of graft copolymers using the macromonomer method is believed very good for those with well-defined structure. We examined the kinetics of radical homopolymerization of methacryloyl and vinylbenzyl-terminated PROZO macromonomers, and found reactivity to be particularly influenced by longer alkyl (R) branches and remarkably enhanced in water. ${ }^{5}$ Previously, radical copolymerization of hydrophilic PROZO macromonomers was found to produce micron to submicron-size polymer particles using the functions of macromonomers as stabilizers or emulsifiers. ${ }^{6}$ Amphiphilic graft copolymers were obtained by copolymerization of hydrophilic PROZO macromonomers with hydrophobic monomers. ${ }^{7}$ The reactivity of $\mathrm{PROZO}$ macromonomers in copolymerizations is of interest, though detailed examination on copolymerizability has not been reported.

In the present study, reactivity of radical copolymerization of $p$-vinylbenzyl (VB)-terminated PMeOZO macro-

$\dagger$ To whom correspondence should be addressed. monomers $(\mathrm{Me}-n ; n$ (degree of polymerization $)=3-31)$ with ordinary vinyl monomers, methyl methacrylate (MMA) and 2-hydroxyethyl methacrylate (HEMA) was examined in ethanol (EtOH), $\mathrm{CD}_{3} \mathrm{OD}$, and $\mathrm{CD}_{3} \mathrm{CN}$. $\mathrm{EtOH}$ and $\mathrm{CD}_{3} \mathrm{OD}$ must be easy to solvate the aprotic PMeOZO chains. MMA is a hydrophobic monomer, while HEMA is hydrophilic monomer with hydroxyl groups. The effects of the properties on the copolymerization are discussed on the basis of monomer reactivity ratios. The reactivity of macromonomers in copolymerization is essentially the same, ${ }^{8}$ or less than ${ }^{9}$ that of corresponding ordinary vinyl monomers. The most effective factor determining reactivity of macromonomers in copolymerization is the chemical nature of the polymerizable end groups of the macromonomers. Other important factors may be; (1) steric effects ${ }^{10}$ including kinetic excluded volume effects, ${ }^{9 d-f, 11}$ (2) thermodynamic repulsive interactions, ${ }^{8 \mathbf{b}, 9 \mathbf{a}, \mathbf{c}}$ (3) viscosity of polymerization systems, and (4) molecular weights of macromonomers. The reactivity of macromonomers has been found in a few cases higher than that of corresponding small monomers, being interpreted in a term of micelle formation. ${ }^{12}$ For the monomer reactivity ratio in copolymerization of macromonomers $\left(\mathrm{M}_{1}\right)$ with ordinary vinyl monomers $\left(\mathrm{M}_{2}\right)$, only $r_{2}$ is generally evaluated because of technical difficulties in determining $r_{1}$ and $r_{2}$. On the basis of $r_{2}$, reactivity only with back bone radicals can be discussed and the nature of reactivity with macromonomer-unit-terminated radicals is normally not detectable. PROZO macromonomers possess characteristic features as mentioned above, and thus determination of reactivity and knowing the reactivity of the macromonomer-unit-terminated radicals become essential. $r_{1}$ and $r_{2}$ in the copolymerization are evaluated and the effects of several factors on reactivity are discussed. 


\section{EXPERIMENTAL}

\section{Materials}

$\mathrm{CH}_{3} \mathrm{CN}$ and $\mathrm{CD}_{3} \mathrm{CN}$ were purified by distillation over $\mathrm{P}_{2} \mathrm{O}_{5}$. EtOH was distilled over ethoxide formed using magnesium. $p$-Vinylbenzyl chloride (VBC) was prepared according to the literature. ${ }^{13}$ 2-Methyl-2-oxazoline (MeOZO) was stirred with $\mathrm{KOH}$ and distilled. $\mathrm{CD}_{3} \mathrm{OD}$, methyl methacrylate (MMA) and 2-hydroxyethyl methacrylate (HEMA) were distilled before use. 2,2'-Azobis(isobutyronitrile) (AIBN) was recrystallized from methanol. Diethyl ether $\left(\mathrm{Et}_{2} \mathrm{O}\right)$ and $n$-hexylbenzene was distilled over sodium wire.

\section{Macromonomers}

p-Vinylbenzyl-terminated PMeOZO macromonomers $(1 \mathrm{Me}-n)$ having a hydroxyl group at $\omega$ end were prepared<smiles>C=Cc1ccc(CN(CCCO)C(C)=O)cc1</smiles>

1 Me-n

Scheme 1.

using the living polymerization of 2-methyl-2-oxazoline (MeOZO). ${ }^{14} \mathrm{MeOZO}$ was heated with $\mathrm{VBC}$ and $\mathrm{NaI}$ as an initiator in $\mathrm{CH}_{3} \mathrm{CN}$ at $80{ }^{\circ} \mathrm{C}$ for $20 \mathrm{~h}$ to give living PROZO, whose propagating species (2-oxazolinium salt) was hydrolyzed by heating with $\mathrm{H}_{2} \mathrm{O}$ and $\mathrm{Na}_{2} \mathrm{CO}_{3}$ at $80^{\circ} \mathrm{C}$ for $20 \mathrm{~h}$ for conversion to the alcohols (1). Macromonomers 1 were purified by reprecipitation from $\mathrm{CHCl}_{3}$ solution with $\mathrm{Et}_{2} \mathrm{O}$ as non-solvents, being shown in Table I. Number average molecular weight $\left(M_{n}\right)$ of 1 was determined by ${ }^{1} \mathrm{H}$ NMR and GPC. In ${ }^{1} \mathrm{H}$ NMR, signal integration ratios of $\mathrm{NCH}_{2}$ protons $(\delta 3.4-3.6)$ to phenylene protons $(\delta 7.19-7.47)$ of styryl groups gave macromonomer chain length $n\left(D P_{n}\right)$, from which $M_{n}$ was calculated. Gel permeation chromatography (GPC) was measured in $\mathrm{CHCl}_{3}$ as eluent using $\mathrm{PMeOZO}$ standards. Molecular weight distributions of the macromonomers were generally narrow, reflecting the living nature of the polymerizations.

\section{Copolymerization}

The radical copolymerization of macromonomers with MMA and HEMA was conducted using AIBN as initiator mainly in EtOH. $1 \mathrm{Me}-3$ and 15 were polymerized in $\mathrm{CD}_{3} \mathrm{OD}$, and $\mathrm{CD}_{3} \mathrm{CN}$.

In polymerization in EtOH, calculated amounts of solutions were mixed in a flask under Ar at $0.05 \mathrm{~g}$ total monomers in $2 \mathrm{~mL}$ solvent. Each $2 \mathrm{~mL}$ of mixture were transferred into glass tubes under $\mathrm{Ar}$ and sealed. One tube was kept at $-10^{\circ} \mathrm{C}$ as the unreacted run for analysis, i.e., UV, gas chromatography (GC), or GPC. Polymerization was carried out at $60^{\circ} \mathrm{C}$. Conversion of macromonomers was determined mainly by change of deviation between an increasing peak at $290 \mathrm{~nm}$ and a decreasing peak at $294 \mathrm{~nm}$ in UV-second order derivative spectra, ${ }^{9 \mathrm{f}}$ or by change of the integration ratio of comonomer peak to internal standard peak in GPC. The conversion of vinyl comonomers was determined by change of the integration ratio of comonomer peak to internal standard
Table I. Vinylbenzyl-type macromonomers of poly(2-methyl-2-oxazoline)

\begin{tabular}{|c|c|c|c|c|}
\hline \multirow{2}{*}{$\begin{array}{l}\text { Macromonomer } \\
\text { (1) }\end{array}$} & \multicolumn{2}{|c|}{$M_{n}$} & \multirow{2}{*}{$D P_{n}{ }^{a}$} & \multirow{2}{*}{$\frac{M_{w}^{\mathrm{a}}}{M_{n}}$} \\
\hline & NMR & GPC & & \\
\hline $\mathrm{Me}-3$ & 410 & 390 & 3.0 & 1.32 \\
\hline Me- 15 & 1380 & 1370 & 14.5 & 1.11 \\
\hline $\mathrm{Me}-28$ & 2500 & 2490 & 27.7 & 1.16 \\
\hline Me-31 & 2830 & 2800 & 31.4 & 1.18 \\
\hline
\end{tabular}

a Determined by GPC.

peak in GC. As the internal standard, $n$-hexylbenzene was used.

In polymerization in $\mathrm{CD}_{3} \mathrm{CN}$ and $\mathrm{CD}_{3} \mathrm{OD}$, a solution of $0.01 \mathrm{~g}$ total monomers, AIBN, and $0.6 \mathrm{~mL}$ solvent was placed into NMR tube $(5 \mathrm{~mm} \phi)$ under Ar and sealed. After heating at $60^{\circ} \mathrm{C}$, the solution was analysed by ${ }^{1} \mathrm{H}$ NMR. Conversion of macromonomers was determined by change of the signal integration ratio of vinylmethylene protons $(\delta 5.2-5.3$ and 5.8) of styryl group to phenylene protons $(\delta 7.2-7.5)$, and that of MMA was assayed by change of the signal integration ratio of vinyl-methylene protons ( $\delta 5.6$ and 6.1$)$ of methacryloyl group to the phenylene protons. Monomer reactivity ratios were evaluated using the conversions on a basis of the integrated equation. ${ }^{15}$

\section{Measurements}

${ }^{1} \mathrm{H}$ and ${ }^{13} \mathrm{C}$ NMR spectra were recorded on a JEOL JNM LA 400 FT NMR spectrometer $\left({ }^{1} \mathrm{H}: 400 \mathrm{MHz}\right)$ with tetramethylsilane as standard. ${ }^{1} \mathrm{H}$ Spin-lattice relaxation times $\left(T_{1}\right)$ in ${ }^{1} \mathrm{H}$ NMR were measured at $\pi / 2$ pulse using the inversion recovery method at $60^{\circ} \mathrm{C}$. Concentrations of macromonomer solutions in $T_{1}$ measurement were nearly $25 \mathrm{~g} \mathrm{~L}^{-1}$ to be analogous to those in actual copolymerization. IR spectra were measured by a JASCO IR-810 spectrophotometer. UVsecond order derivative spectra were acquired on a SHIMADZU UV-2200 spectrophotometer. GPC analysis was performed using a SHIMADZU LC-10AD chromatograph equipped with a SHIMADZU RID-6A RI detector. GPC columns, a SHODEX AC-803 and a JASCO Fine Pack Gel-101 were connected in series $\left(M_{n}\right.$ at exclusion limit, $7 \times 10^{4}$ ), and $\mathrm{CHCl}_{3}$ was used as eluent at $0.8 \mathrm{~mL} \mathrm{~min}^{-1}$. Molecular weights were determined relative to $\mathrm{PMeOZO}$ standards prepared by polymerization of MeOZO by MeOTs as an initiator. GC analysis was carried out with a SHIMADZU GC-R1A gas chromatograph equipped with a flame ionization detector. As stationary phase in GC, Polyester-FF supported on Chromosorb-101 (NISHIO) was employed for MMA analysis, while Thermon-3000 supported on Shincarbon-A (SHIMADZU) was used for analysis of HEMA.

\section{RESULTS AND DISCUSSION}

\section{Copolymer Composition}

Radical copolymerizations of VB-PMeOZO macromonomers (1 Me- $n$ ) with MMA (hydrophobic) and HEMA (hydrophilic and protic) were carried out using AIBN as an initiator in EtOH $(n=3,15$, and 31$), \mathrm{CD}_{3} \mathrm{OD}$ 
Table II. Copolymerization of $1 \mathrm{Me}-3\left(\mathrm{M}_{1}\right)$ with $\mathrm{MMA}\left(\mathrm{M}_{2}\right)$ in $\mathrm{EtOH}^{\mathrm{a}}$

\begin{tabular}{|c|c|c|c|c|c|c|c|c|c|}
\hline \multirow{3}{*}{ Run } & \multicolumn{5}{|c|}{ Feed composition } & \multirow{3}{*}{$\begin{array}{c}\text { Time } \\
\mathrm{h}\end{array}$} & \multirow{2}{*}{\multicolumn{2}{|c|}{$\begin{array}{l}\text { Monomer } \\
\text { conversion }\end{array}$}} & \multirow{3}{*}{$\begin{array}{c}\begin{array}{c}\mathrm{M}_{1} \text { in } \\
\text { copolymer }\end{array} \\
\mathrm{mol} \%\end{array}$} \\
\hline & \multicolumn{2}{|c|}{$\left[\mathrm{M}_{1}\right]_{0}$} & \multicolumn{2}{|c|}{$\left[\mathrm{M}_{2}\right]_{0}$} & \multirow{2}{*}{$\frac{\mathrm{M}_{1}}{\operatorname{mol} \%}$} & & & & \\
\hline & $\mathrm{mg}$ & $\begin{array}{l}\mathrm{mol} \mathrm{L}^{-1} \\
\left(\times 10^{2}\right)\end{array}$ & $\mathrm{mg}$ & $\begin{array}{l}\mathrm{mol} \mathrm{L}^{-1} \\
\left(\times 10^{2}\right)\end{array}$ & & & $\frac{\mathrm{M}_{1}^{\mathrm{b}}}{\%}$ & $\frac{\mathrm{M}_{2}^{\mathrm{c}}}{\%}$ & \\
\hline 1 & 20.66 & 2.60 & 29.43 & 14.70 & 15.0 & 10 & 8.9 & 1.9 & 44.7 \\
\hline 2 & 27.10 & 3.45 & 23.01 & 11.50 & 23.1 & 16 & 6.3 & 1.3 & 58.8 \\
\hline 3 & 31.38 & 4.00 & 18.51 & 9.25 & 30.2 & 22 & 9.6 & 2.2 & 65.2 \\
\hline 4 & 38.06 & 4.85 & 11.78 & 5.90 & 45.1 & 32 & 7.3 & 2.2 & 72.9 \\
\hline 5 & 42.90 & 5.45 & 7.25 & 3.60 & 60.2 & 36 & 12.8 & 5.8 & 76.9 \\
\hline 6 & 45.08 & 5.70 & 5.02 & 2.50 & 69.5 & 36 & 8.1 & 5.2 & 77.9 \\
\hline 7 & 46.01 & 5.85 & 3.84 & 1.90 & 75.5 & 44 & 10.4 & 8.6 & 78.7 \\
\hline 8 & 48.65 & 6.17 & 1.31 & 0.65 & 90.5 & 48 & 7.7 & 10.6 & 86.7 \\
\hline
\end{tabular}

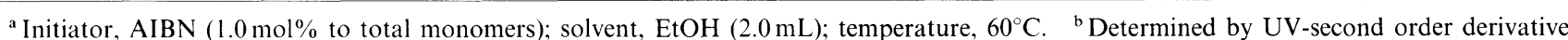
spectroscopy. ${ }^{\mathrm{c}}$ Determined by GC.

$\left(n=3\right.$ and 15), and $\mathrm{CD}_{3} \mathrm{CN}(n=3$ and 15$)$ at $60^{\circ} \mathrm{C}$. Copolymerizability is affected by increased viscosity of reaction system resulting from proceeding of the reaction, ${ }^{10 \mathrm{a}}$ and thus, reactivity at lower conversion of monomers below about $10 \%$ was determined. Monomer reactivity ratios were obtained using the integrated equation on the basis of the copolymerization equation (eq 1). ${ }^{15}$

$$
\frac{\mathrm{d}\left[\mathrm{M}_{1}\right]}{\mathrm{d}\left[\mathrm{M}_{2}\right]}=\frac{r_{1}\left[\mathrm{M}_{1}\right]+\left[\mathrm{M}_{2}\right]}{\left[\mathrm{M}_{1}\right]+r_{2}\left[\mathrm{M}_{2}\right]} \frac{\left[\mathrm{M}_{1}\right]}{\left[\mathrm{M}_{2}\right]}
$$

where $M_{1}$ and $M_{2}$ denote monomers 1 and vinyl monomers 2 (MMA and HEMA) and $r_{1}$ and $r_{2}$ are respective monomer reactivity ratios.

When copolymers can be completely separated from unreacted monomers, compositions can be determined by analysis of them. When complete separation is impossible, it is rather suitable to determine the copolymer composition using monomer conversion. ${ }^{16}$ For estimation of monomer conversion, unreacted monomers are largely determined by GPC for macromonomers and by GC for vinyl comonomers. In the present work, the complete separation of copolymers produced from unreacted monomers was impossible. Therefore, copolymer composition was evaluated by monomer conversion. In copolymerization in $\mathrm{EtOH}$, conversions of macromonomers were determined by UV-second order derivative spectra, and those of the vinyl monomers, by GC. UV-fourth order derivative spectra are used for analysis of styryl-type polyamine macromonomers. ${ }^{9 f}$ Unreacted macromonomers in polymerization solutions of $1 \mathrm{Me}-15$ of lower mole fraction were analysed by GPC for confirmation of UV. In the copolymerization in $\mathrm{CD}_{3} \mathrm{OD}$ and $\mathrm{CD}_{3} \mathrm{CN}$, conversion of monomers was determined by changes of signal integration ratios of respective vinyl protons to phenylene protons in ${ }^{1} \mathrm{H}$ NMR spectra.

\section{Copolymerizability}

In EtOH, copolymerizations of $1 \mathrm{Me}-3$ and 15 with MMA or HEMA, of $1 \mathrm{Me}-31$ with MMA and 1 Me-28 with HEMA were examined. In the copolymerization of $1 \mathrm{Me}-3$ and 15 with MMA or HEMA, $\mathrm{CD}_{3} \mathrm{OD}$ and $\mathrm{CD}_{3} \mathrm{CN}$ were used as reaction solvents.

Results of the copolymerization of 1 Me-3 with MMA
Table III. Conversions of $1 \mathrm{Me}-15\left(\mathrm{M}_{1}\right)$ and comonomers $\left(\mathrm{M}_{2}\right)$ in copolymerization in $\mathrm{EtOH}$

\begin{tabular}{|c|c|c|c|c|c|c|}
\hline \multirow{3}{*}{ Run } & \multirow{3}{*}{$\mathrm{M}_{2}$} & \multirow{3}{*}{$\begin{array}{c}\mathrm{M}_{1} \\
\mathrm{~mol} \%\end{array}$} & \multirow{3}{*}{$\frac{\text { Time }}{\mathrm{h}}$} & \multicolumn{3}{|c|}{ Conversion } \\
\hline & & & & \multicolumn{2}{|c|}{$\mathrm{M}_{1} \%$} & \multirow{2}{*}{$\begin{array}{r}\mathrm{M}_{2}^{\mathrm{a}} \\
\%\end{array}$} \\
\hline & & & & UV & GPC & \\
\hline 9 & MMA & 3.6 & 10 & 12.1 & 11.9 & 2.4 \\
\hline 10 & MMA & 6.2 & 15 & 7.8 & 7.5 & 1.5 \\
\hline 11 & HEMA & 4.3 & 17 & 11.5 & 11.0 & 2.7 \\
\hline 12 & HEMA & 7.2 & 20 & 9.4 & 9.9 & 2.2 \\
\hline
\end{tabular}

${ }^{a}$ Determined by GC.

in EtOH are shown in Table II. In the copolymerization of $1 \mathrm{Me}-15$ with MMA or HEMA in EtOH, macromonomer conversions were determined in part (mole fraction of macromonomers: 3.6 to 7.2 ) by GPC, being very close to those determined by UV-second order derivative spectroscopy as shown in Table III. Therefore, adequateness of determining macromonomer conversion by UV was confirmed. Copolymerization rate decreased with increase in mole fractions of macromonomers in the feed and macromonomer chain length $(n)$. This is general trend for copolymerizations of macromonomers.

Copolymer composition curves calculated from the monomer reactivity ratios on the basis of eq 1 are shown in Figures 1 and 2 (1 Me-3, 15, and 31 with MMA in EtOH), Figure 3 (1 Me-3 and 15 with MMA in $\left.\mathrm{CD}_{3} \mathrm{OD}\right)$, Figure 4 ( $1 \mathrm{Me}-3$ with $\mathrm{MMA}$ in $\mathrm{CD}_{3} \mathrm{CN}$ ), and Figure 5 (1 Me-3, 15, and 28 with HEMA in EtOH). The plots of feed composition versus copolymer composition were generally in agreement with the calculated curves, but, deviated considerably from those for the copolymerization of $1 \mathrm{Me}-3$ with MMA or HEMA in EtOH.

First, copolymerization with MMA is described below. The polymerization of $1 \mathrm{Me}-3\left(\mathrm{M}_{1}\right)$ with $\mathrm{MMA}\left(\mathrm{M}_{2}\right)$ in EtOH gave reactivity ratios of $r_{1}=1.86 \pm 0.15$ and $r_{2}=0.07 \pm 0.03$ (Table II, Figure 1). This means that the reactivity of $1 \mathrm{Me}-3$ is much higher than that of MMA against both of macromonomer-unit-terminated radical $\left(M_{1} \cdot\right)$ and MMA-unit-terminated radical $\left(\mathbf{M}_{2} \cdot\right)$, and even than that of styrene in the copolymerization of styrene $\left(\mathrm{M}_{1}\right)$ and MMA $\left(\mathrm{M}_{2}\right)$ in EtOH; $r_{1}=0.40$ and $r_{2}=0.45$. $^{17} r_{2}$ suggests probability of mutual bind- 


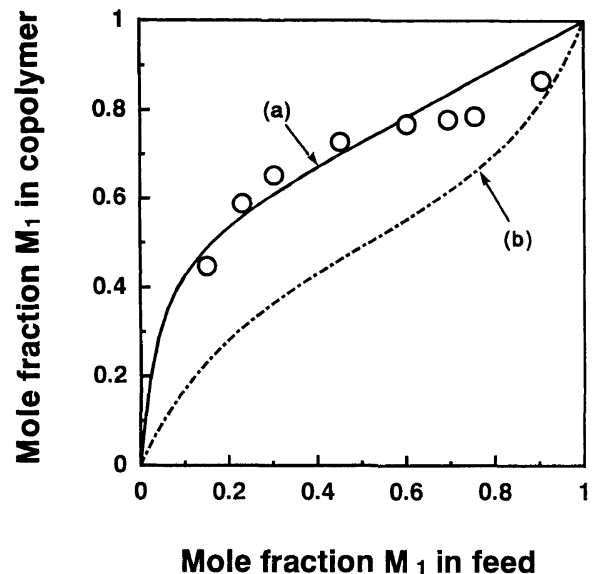

Figure 1. Monomer feed versus copolymer composition plots for copolymerization of $1 \mathrm{Me}-3\left(\mathrm{M}_{1}\right)$ with MMA $\left(\mathrm{M}_{2}\right)$ in EtOH: (a) calculated curve for the copolymerization $\left(r_{1}=1.86 \pm 0.15, r_{2}=0.07 \pm\right.$ 0.03 ); (b) calculated curve for polymerization of styrene with MMA $\left(r_{1}=0.40, r_{2}=0.45\right)$.

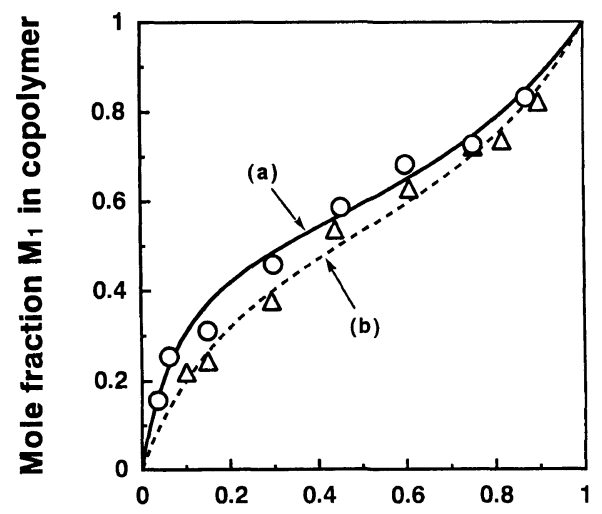

Mole fraction $M_{1}$ in feed

Figure 2. Monomer feed versus copolymer composition plots for copolymerization of $1 \mathrm{Me}-15$ or $\mathbf{1} \mathrm{Me}-31\left(\mathrm{M}_{1}\right)$ with MMA $\left(\mathrm{M}_{2}\right)$ in EtOH: $(\bigcirc)$ plots for $1 \mathrm{Me}-15$ and MMA; $(\triangle)$ plots for $1 \mathrm{Me}-31$ and MMA; (a) calculated curve for $1 \mathrm{Me}-15$ and MMA $\left(r_{1}=0.70 \pm 0.10\right.$, $\left.r_{2}=0.16 \pm 0.04\right)$; (b) calculated curve for $1 \mathrm{Me}-31$ and MMA $\left(r_{1}=\right.$ $0.55 \pm 0.10, r_{2}=0.36 \pm 0.05$ ).

ing of MMA is extremely low. With increase in $n, r_{1}$ decreased and $r_{2}$ increased (Figure 2). The reactivity of macromonomers $\left(\mathrm{M}_{1}\right)$ may thus be lowered with $n$ against both growing radicals, $\mathbf{M}_{1} \cdot$ and $\mathbf{M}_{2} \cdot$. Particularly, large change in $r_{1}$ values can be found between at $n=3$ and $n=15$, that is, $r_{1}=0.70 \pm 0.10$ at $n=15$. However at $n=31$, the reactivity ratios were given as $r_{1}=0.55 \pm 0.10$ and $r_{2}=0.36 \pm 0.05$, which showed higher reactivity of VB-PMeOZO macromonomers $\left(\mathrm{M}_{1}\right)$ compared with that of styrene in the styrene-MMA copolymerization system ${ }^{17}$ even at such large $n$. In the copolymerization with $\mathrm{MMA}$ in $\mathrm{CD}_{3} \mathrm{OD}, 1 \mathrm{Me}-3$ gave $r_{1}=1.25 \pm 0.10$ and $r_{2}=0.18 \pm 0.05$, while $1 \mathrm{Me}-15$ gave $r_{1}=0.53 \pm 0.10$ and $r_{2}=0.31 \pm 0.05$ (Figure 3 ), to indicate the higher reactivity of $1 \mathrm{Me}-3$ and decrease in reactivity with increase in $n$ similar to polymerization in $\mathrm{EtOH}$. In the copolymerization with $\mathrm{MMA}$ in $\mathrm{CD}_{3} \mathrm{CN}, 1 \mathrm{Me}-3$ gave $r_{1}=0.41 \pm 0.10$ and $r_{2}=0.66 \pm 0.10$ (Table IV and Figure 4), while $1 \mathrm{Me}-15$ gave $r_{1}=0.35 \pm 0.08$ and $r_{2}=0.83 \pm 0.10$, showing extremely lowered reactivity especially in $1 \mathrm{Me}-3$ compared with that in alcohol

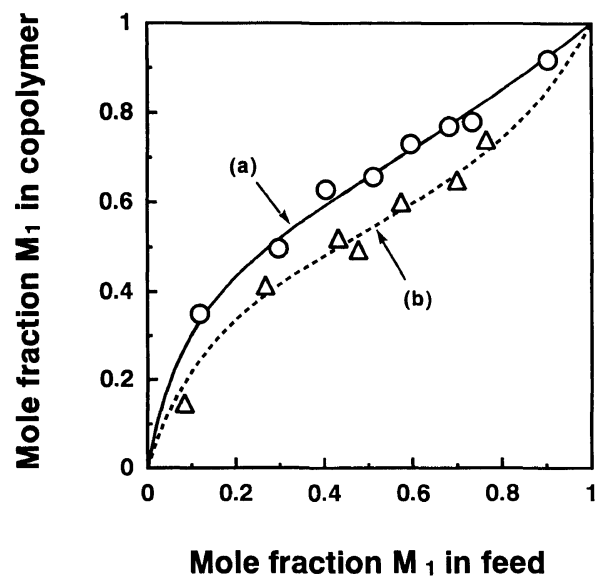

Figure 3. Monomer feed versus copolymer composition plots and calculated curve for copolymerization of $1 \mathrm{Me}-3$ or $1 \mathrm{Me}-15\left(\mathrm{M}_{1}\right)$ with MMA $\left(\mathrm{M}_{2}\right)$ in $\mathrm{CD}_{3} \mathrm{OD}$ : $(\bigcirc)$ plots for $1 \mathrm{Me}-3$ and MMA; $(\triangle)$ plots for $1 \mathrm{Me}-15$ and MMA; (a) calculated curve for $1 \mathrm{Me}-3$ and MMA $\left(r_{1}=1.25 \pm 0.10, r_{2}=0.18 \pm 0.05\right)$; (b) calculated curve for $1 \mathrm{Me}-15$ and MMA $\left(r_{1}=0.53 \pm 0.10, r_{2}=0.31 \pm 0.05\right)$.

solvents.

In many cases reported previously, radical copolymerizability of macromonomers $\left(\mathrm{M}_{1}\right)$ has been argued only on the basis of $r_{2}$ in copolymerization with large excess of comonomers $\left(\mathrm{M}_{2}\right)$, and generally concluded that it does not differ ${ }^{8}$ or decreases ${ }^{9}$ from that of the corresponding small monomers. However, the present copolymerization in $\mathrm{EtOH}$ and $\mathrm{CD}_{3} \mathrm{OD}$ indicate $\mathrm{PMeOZO}$ macromonomers of smaller $n$ exhibit significantly higher reactivity than that of MMA and even styrene as described above. It is scarcely acceptable that the chemical reactivity of styryl group would be so strongly influenced by $\mathrm{PMeOZO}$ chain attached at para position in the same molecule. In ${ }^{13} \mathrm{C}$ NMR spectra, chemical shifts of methylene and methine carbons in vinyl groups in $\mathrm{CD}_{3} \mathrm{CN}$ were $\delta 112.22$ and 125.94 for 4-methylstyrene (MeSt), 112.87 and 125.88 for $1 \mathrm{Me}-3$, and 112.86 and 125.86 for $1 \mathrm{Me}-15$, respectively, supporting above concept.

To follow up macromonomer reactivity, spin-lattice relaxation times $\left(T_{1}\right)$ in ${ }^{1} \mathrm{H}$ NMR of the macromonomers and a model compound MeSt were measured in $\mathrm{CD}_{3} \mathrm{CN}$, $\mathrm{CD}_{3} \mathrm{OD}$, and $\mathrm{C}_{2} \mathrm{D}_{5} \mathrm{OD}$ by inversion recovery at 400 $\mathrm{MHz}$ at $60^{\circ} \mathrm{C}$. ${ }^{1} \mathrm{H}$ NMR relaxation is a simple means to estimate the mobility of molecules, although influenced by intermolecular contributions. ${ }^{18}$ The results of $T_{1}$ measurement on five protons $(\mathrm{A}-\mathrm{E})$ are listed in Table $\mathrm{V}$. Relaxation times of the macromonomers were much shorter than those of MeSt and decreased with increase in $n$. $T_{1}$ of the macromonomers in $\mathrm{CD}_{3} \mathrm{CN}, \mathrm{CD}_{3} \mathrm{OD}$, and $\mathrm{C}_{2} \mathrm{D}_{5} \mathrm{OD}$ decreased in that order. Decrease in $T_{1}$ of the macromonomers in $\mathrm{C}_{2} \mathrm{D}_{5} \mathrm{OD}$ from that in $\mathrm{CD}_{3} \mathrm{CN}$ was much higher than in MeSt. $T_{1}$ of MeSt in $\mathrm{CD}_{3} \mathrm{OD}$ were rather higher than in $\mathrm{CD}_{3} \mathrm{CN}$. Vinylbenzyl-ended PMeOZO macromonomers $1(n=13$ and 34) lowered surface tension $(\gamma)$ of water to exhibit surfactant properties. $^{14} T_{1}$ of protons $\mathrm{A}-\mathrm{C}$ of macromonomers 1 determined in $\mathrm{C}_{2} \mathrm{D}_{5} \mathrm{OD}$ were closer to $T_{1}$ in $\mathrm{D}_{2} \mathrm{O}$ rather than in $\mathrm{CD}_{3} \mathrm{CN}$, and fairly close to those in a $\mathrm{C}_{2} \mathrm{D}_{5} \mathrm{OD}-\mathrm{D}_{2} \mathrm{O}$ mixture $\left(\mathrm{C}_{2} \mathrm{D}_{5} \mathrm{OD} 80 \mathrm{wt} \%\right)$, in which the micellar state of macromonomers may be presumed. In 
Table IV. Copolymerization of $1 \mathrm{Me}-3\left(\mathrm{M}_{1}\right)$ with $\mathrm{MMA}\left(\mathrm{M}_{2}\right)$ in $\mathrm{CD}_{3} \mathrm{CN}^{\mathrm{a}}$

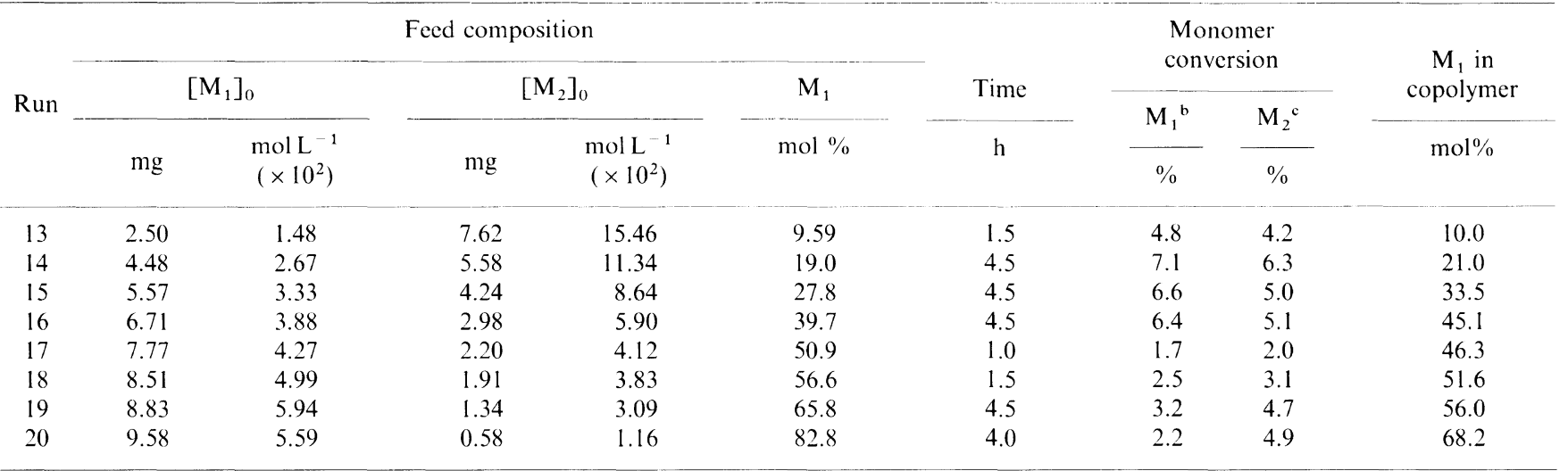

${ }^{a}$ Total monomers, $0.01 \mathrm{~g}$; initiator, $\mathrm{AIBN}\left(1.0 \mathrm{~mol} \%\right.$ to total monomers); solvent, $\mathrm{CD}_{3} \mathrm{CN}(0.6 \mathrm{ml})$; temperature, $60{ }^{\circ} \mathrm{C}$. ${ }^{\mathrm{b}} \mathrm{Determined} \mathrm{by}{ }^{1} \mathrm{H}$ NMR

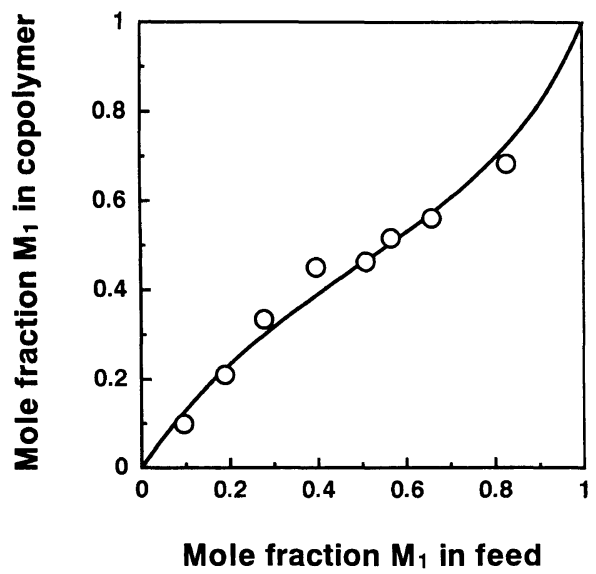

Figure 4. Monomer feed versus copolymer composition plots and calculated curve for copolymerization of plots for $1 \mathrm{Me}-3\left(\mathrm{M}_{1}\right)$ with $\mathrm{MMA}\left(\mathrm{M}_{2}\right)$ in $\mathrm{CD}_{3} \mathrm{CN}\left(r_{1}=0.41 \pm 0.10, r_{2}=0.66 \pm 0.10\right)$

copolymerization of vinylbenzyl-ended poly (4-vinyl- $N$ $n$-butylpyridinium bromide) macromonomer with styrene in an EtOH- $\mathrm{H}_{2} \mathrm{O}$ mixture reported by Riza, micelle formation of macromonomers is proposed. ${ }^{12 \mathrm{c}}$ The relaxation behavior suggests that present macromonomers take on a micelle-like state in $\mathrm{C}_{2} \mathrm{D}_{5} \mathrm{OD}$ and $\mathrm{CD}_{3} \mathrm{OD}$, although the state may not be so stable. The alcohols may solvate easily PMeOZO chains of aprotic nature by forming hydrogen bond between hydroxyl and carbonyl groups of PMeOZO. In $1 \mathrm{Me}-15$ and 31, $T_{1}$ of $\mathrm{D}$ and $\mathrm{E}$ in the alcohol solvents were little different from those in $\mathrm{CD}_{3} \mathrm{CN}$, while $T_{1}$ of styryl protons (A, B, and C) in the alcohols differed from those in $\mathrm{CD}_{3} \mathrm{CN}$. This seems to support the micelle-like state of macromonomers, in which styryl groups may aggregate weakly inside. Macromonomers $\mathbf{1}$ may aggregate with macromonomer units in growing chains.

The higher reactivity of $1 \mathrm{Me}-n$ in the copolymerization in $\mathrm{EtOH}$ and $\mathrm{CD}_{3} \mathrm{OD}$ can be explained on the basis of the aggregation of macromonomers, and that of macromonomers and growing chains. In the latter, macromonomers should be concentrated about growing sites. MMA may disperse homogeneously in EtOH solution. Increase of macromonomer reactivity by micelle formation in copolymerization with convensional small monomers has been reported. ${ }^{12}$ In $\mathrm{CD}_{3} \mathrm{CN}$, macro-
Table V. ${ }^{1} \mathrm{H}$ Spin-lattice relaxation times $\left(\mathrm{T}_{1}\right)$ of macromonomers and 4-methylstyrene $(\mathrm{MeSt})$ measured at $400 \mathrm{MHz}\left(60.0^{\circ} \mathrm{C}\right)$

\begin{tabular}{|c|c|c|c|c|c|c|c|}
\hline \multirow{2}{*}{ Entry } & \multirow{2}{*}{ Monomer } & \multirow{2}{*}{ Solvent } & \multicolumn{5}{|c|}{ Relaxation time/s } \\
\hline & & & A & B & $\mathrm{C}$ & $\mathrm{D}$ & $\mathrm{E}$ \\
\hline 1 & MeSt & $\mathrm{CD}_{3} \mathrm{CN}$ & 7.63 & 7.49 & 9.86 & - & - \\
\hline 2 & MeSt & $\mathrm{CD}_{3} \mathrm{OD}$ & 9.79 & 8.93 & 13.25 & - & - \\
\hline 3 & $\mathrm{MeSt}$ & $\mathrm{C}_{2} \mathrm{D}_{5} \mathrm{OD}$ & 6.05 & 5.76 & 7.34 & - & - \\
\hline 4 & $\mathrm{Me}-3$ & $\mathrm{CD}_{3} \mathrm{CN}$ & 3.02 & 2.38 & 3.89 & 0.58 & 2.02 \\
\hline 5 & $\mathrm{Me}-3$ & $\mathrm{CD}_{3} \mathrm{OD}$ & 2.09 & 1.73 & 2.74 & 0.50 & 1.30 \\
\hline 6 & $\mathrm{Mc}-3$ & $\mathrm{C}_{2} \mathrm{D}_{5} \mathrm{OD}$ & 1.73 & 1.30 & 2.16 & 0.35 & 0.86 \\
\hline 7 & Me- 15 & $\mathrm{CD}_{3} \mathrm{CN}$ & 2.30 & 1.87 & 3.17 & 0.36 & 0.86 \\
\hline 8 & Me-15 & $\mathrm{CD}_{3} \mathrm{OD}$ & 1.80 & 1.44 & 2.45 & 0.33 & 0.86 \\
\hline 9 & Me-15 & $\mathrm{C}_{2} \mathrm{D}_{5} \mathrm{OD}$ & 1.51 & 1.15 & 2.16 & 0.30 & 0.86 \\
\hline 10 & $\mathrm{Me}-31$ & $\mathrm{CD}_{3} \mathrm{CN}$ & 2.02 & 1.66 & 2.88 & 0.32 & 0.79 \\
\hline 11 & $\mathrm{Me}-31$ & $\mathrm{C}_{2} \mathrm{D}_{5} \mathrm{OD}$ & 1.44 & 1.08 & 2.02 & 0.29 & 0.79 \\
\hline 12 & $\mathrm{Me}-3$ & $\mathrm{C}_{2} \mathrm{D}_{5} \mathrm{OD}$ & & & & & \\
\hline 13 & $\mathrm{Me}-15$ & $\begin{array}{c}\mathrm{D}_{2} \mathrm{O}^{\mathrm{a}} \\
\mathrm{C}_{2} \mathrm{D}_{5} \mathrm{OD}\end{array}$ & 1.44 & 1.15 & 1.73 & 0.32 & 0.86 \\
\hline & & $\mathrm{D}_{2} \mathrm{O}^{\mathrm{a}}$ & 1.22 & 1.01 & 1.73 & 0.32 & 0.72 \\
\hline 14 & Me-15 & $\mathrm{D}_{2} \mathrm{O}$ & 0.95 & 0.86 & 1.44 & 0.30 & 0.72 \\
\hline
\end{tabular}

${ }^{a} \mathrm{C}_{2} \mathrm{D}_{5} \mathrm{OD} 80 \mathrm{wt} \%$.<smiles>CCCCN(CCCC)C(C)=O</smiles>

$1 \mathrm{Me}-\mathrm{n}$<smiles>[1H]C=Cc1ccc(C)cc1</smiles>

$\mathrm{MeSt}$ monomers 1 may constitute a homogeneous solution.

The apparent reactivity of $\mathrm{PMeOZO}$ macromonomers in the present copolymerization decreased with increase in $n$, but the chemical reactivity of the VB group cannot be considered to decrease so easily. The most probable cause for this may be steric hindrance due to augmentation in segment density around growing sites. By increase in segment density and macromonomer chain length $(n)$, interpenetration of growing ends and polymerizable end groups must be sterically depressed.

Poly(methyl methacrylate)(PMMA) is incompatible 


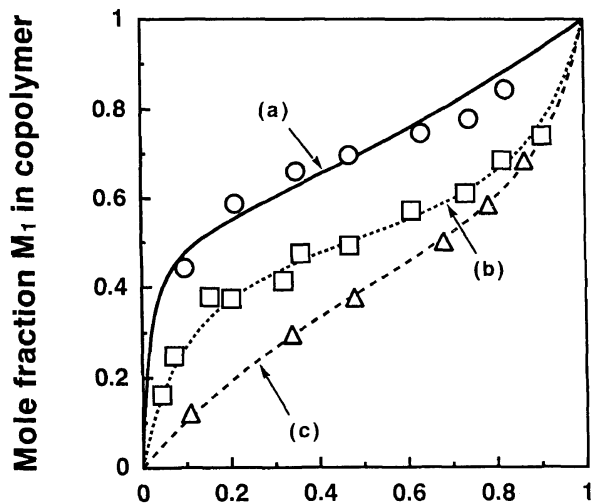

\section{Mole fraction $M_{1}$ in feed}

Figure 5. Monomer feed versus copolymer composition plots for copolymerization of $1 \mathrm{Me}-3, \mathbf{1} \mathrm{Me}-15$ or $1 \mathrm{Me}-28\left(\mathrm{M}_{1}\right)$ with HEMA $\left(\mathrm{M}_{2}\right)$ in EtOH: $(\bigcirc)$ plots for $1 \mathrm{Me}-3$ and HEMA; $(\square)$ plots for 1 Me-15 and HEMA; $(\triangle)$ plots for 1 Me-28 and HEMA; (a) calculated curve for $1 \mathrm{Me}-3$ and HEMA $\left(r_{1}=1.44 \pm 0.10, r_{2}=0.04 \pm 0.02\right)$; (b) calculated curve for $1 \mathrm{Me}-15$ and HEMA $\left(r_{1}=0.26 \pm 0.05, r_{2}=0.20 \pm\right.$ $0.05)$; (c) calculated curve for $1 \mathrm{Me}-28$ and HEMA $\left(r_{1}=0.21 \pm 0.05\right.$, $\left.r_{2}=0.86 \pm 0.10\right)$

Table VI. Monomer reactivity ratios ${ }^{\mathrm{a}}$

\begin{tabular}{|c|c|c|c|c|}
\hline $\begin{array}{c}\text { Macromonomer } \\
\left(\mathrm{M}_{1}\right)\end{array}$ & $\begin{array}{l}\text { Comonomer } \\
\left(\mathrm{M}_{2}\right)\end{array}$ & Solvent & $r_{1}$ & $r_{2}$ \\
\hline $\mathrm{Me}-3$ & MMA & $\mathrm{EtOH}$ & $1.86 \pm 0.15$ & $0.07 \pm 0.03$ \\
\hline Me-15 & MMA & $\mathrm{EtOH}$ & $0.70 \pm 0.10$ & $0.16 \pm 0.04$ \\
\hline $\mathrm{Me}-31$ & MMA & $\mathrm{EtOH}$ & $0.55 \pm 0.10$ & $0.36 \pm 0.05$ \\
\hline $\mathrm{Me}-3$ & MMA & $\mathrm{CD}_{3} \mathrm{OD}$ & $1.25 \pm 0.10$ & $0.18 \pm 0.05$ \\
\hline Me-15 & MMA & $\mathrm{CD}_{3} \mathrm{OD}$ & $0.53 \pm 0.10$ & $0.31 \pm 0.05$ \\
\hline $\mathrm{Me}-3$ & MMA & $\mathrm{CD}_{3} \mathrm{CN}$ & $0.41 \pm 0.10$ & $0.66 \pm 0.10$ \\
\hline $\mathrm{Me}-15$ & MMA & $\mathrm{CD}_{3} \mathrm{CN}$ & $0.35 \pm 0.08$ & $0.83 \pm 0.10$ \\
\hline $\mathrm{Me}-3$ & HEMA & EtOH & $1.44 \pm 0.10$ & $0.04 \pm 0.02$ \\
\hline $\mathrm{Me}-15$ & HEMA & $\mathrm{EtOH}$ & $0.26 \pm 0.05$ & $0.20 \pm 0.05$ \\
\hline Me-28 & HEMA & $\mathrm{EtOH}$ & $0.21 \pm 0.05$ & $0.86 \pm 0.10$ \\
\hline $\mathrm{Me}-3$ & HEMA & $\mathrm{CD}_{3} \mathrm{CN}$ & $0.38 \pm 0.08$ & $0.75 \pm 0.10$ \\
\hline $\mathrm{Me}-15$ & HEMA & $\mathrm{CD}_{3} \mathrm{CN}$ & $0.30 \pm 0.05$ & $0.93 \pm 0.10$ \\
\hline
\end{tabular}

${ }^{a}$ Evaluated based on macromonomer conversions using integrated equation. ${ }^{\mathrm{b}}$ Conversions were determined by UV-second order derivative spectra(reaction in $\mathrm{EtOH}$ ) or ${ }^{1} \mathrm{H} \mathrm{NMR}$ (reaction in $\mathrm{CD}_{3} \mathrm{OD}$ and $\mathrm{CD}_{3} \mathrm{CN}$ ). ${ }^{\mathrm{c}}$ Conversions were determined by $\mathrm{GC}$ (reaction in $\mathrm{EtOH}$ ) or ${ }^{1} \mathrm{H}$ NMR (reaction in $\mathrm{CD}_{3} \mathrm{OD}$ and $\mathrm{CD}_{3} \mathrm{CN}$ ).

with poly(2-ethyl-2-oxazoline), ${ }^{19}$ and thus should also be with PMeOZO. Consequently, if PMMA chain length at a growing site increases in the copolymerization of PMeOZO macromonomers $\left(\mathrm{M}_{1}\right)$ with $\mathrm{MMA}\left(\mathrm{M}_{2}\right)$, incompatibility of macromonomers with the MMAterminated radicals $\left(\mathrm{M}_{2} \cdot\right)$ should cause greater decrease in macromonomer reactivity. The present copolymerization is not of a comonomer-large-excess system to be generally used. Therefore, it may be little influenced by the incompatible effect proposed by Ito in the copolymerization of poly(ethylene oxide) macromonomers. ${ }^{9 a}$

The copolymerization of $1 \mathrm{Me}-n\left(\mathrm{M}_{1}\right)$ with HEMA $\left(\mathrm{M}_{2}\right)$ was examined. HEMA may possess affinity to aprotic $\mathrm{PMeOZO}$ branches on growing chains by forming hydrogen bonds of hydroxyl groups with $N$-acetyl groups. In copolymerization in $\mathrm{EtOH}, r_{1}$ was $1.44 \pm 0.10$ at $n=3$ showing unusual reactivity of the macromonomer as in polymerization with MMA (Figure 5). The value fell to $0.26 \pm 0.05$ at $n=15$ indicating remarkable decrease in macromonomer reactivity toward $\mathrm{M}_{1} \cdot r_{2}$ increased with $n$, exhibiting decrease in macromonomer reactivity toward $\mathrm{M}_{2} \cdot$. At $n=28$, relative reactivity of VB-PMeOZO macromonomers with HEMA can be lower than that of styrene in the copolymerization of styrene $\left(\mathrm{M}_{1}\right)$ and HEMA $\left(\mathrm{M}_{2}\right)$ in 2-propanol in which $r_{1}=0.53$ and $r_{2}=0.59 .^{20}$ The relative reactivity of HEMA should be somewhat higher than that of MMA toward $\mathrm{M}_{1} \cdot$ and $\mathrm{M}_{2} \cdot$. The reason for the higher relative reactivity of HEMA compared with MMA is that HEMA should access more easily propagating sites by forming hydrogen bonds to PMeOZO branches. The decrease of macromonomer reactivity with increase in $n$ can be interpreted similarly to the copolymerization with MMA. In copolymerization with $\mathrm{HEMA}$ in $\mathrm{CD}_{3} \mathrm{CN}$, such higher reactivity of $1 \mathrm{Me}-3$ as in EtOH was not observed and with increase in $n$, reactivity of $1 \mathrm{Me}-n$ toward $\mathrm{M}_{1} \cdot$ and $\mathrm{M}_{2} \cdot$ decreased (Table VI).

Monomer reactivity ratios in the present polymerization using feed composition and monomer conversion are listed in Table VI.

Thus, hydrophilic PMeOZO macromonomers exhibited unusually higher reactivity in copolymerization with MMA and HEMA in EtOH especially at smaller n, possibly due to "macromonomer concentration effect". The shapes of copolymer composition curves in copolymerizations 1 Me-3-MMA and 1 Me-3-HEMA were remarkably similar to those in the "bootstrap model" of Harwood, ${ }^{21}$ suggesting copolymerization behavior to deviate from the terminal model. Also other cases in the present copolymerization of $1 \mathrm{Me}-n$ in the alcohol solvents, may be regarded incompatible with the terminal model, although copolymer composition curves from $r_{1}$ and $r_{2}$ appeared consistent with plots of mole fraction macromonomers in copolymer versus mole fraction macromonomers in the feed.

\section{CONCLUSIONS}

The reactivity of radical copolymerization of macromonomers $1 \mathrm{Me}-n\left(\mathrm{M}_{1}\right)$ possessing aprotic nature with MMA and HEMA $\left(\mathrm{M}_{2}\right)$ was examined in EtOH, $\mathrm{CD}_{3} \mathrm{OD}$, and $\mathrm{CD}_{3} \mathrm{CN}$. Monomer reactivity ratios $r_{1}$ and $r_{2}$ were evaluated on the basis of the terminal model.

In alcohol solvents, $1 \mathrm{Me}-n$ with especially the shortest chain length $(n=3)$ exhibited remarkably higher reactivity than MMA, toward $\mathrm{M}_{1} \cdot$ and $\mathrm{M}_{2} \cdot$. In copolymerization with HEMA, $1 \mathrm{Me}-3$ showed high reactivity in EtOH. The reason for the high reactivity of the macromonomers is the micelle-like state.

Reactivity of macromonomers decreased with $n$, probably due to increase in steric hindrance to interpenetration of polymerizable end groups and growing sites.

The reactivity of HEMA in the present copolymerizations was higher than that of MMA, possibly due to forming hydrogen bonds in PMeOZO graft chains.

In copolymerization in $\mathrm{CD}_{3} \mathrm{CN}$, macromonomers of even $n=3$, showed lower reactivity than comonomers.

\section{REFERENCES}

1. (a) S. Kobayashi, Prog. Polym. Sci., 15, 751 (1990). (b) H. Uyama and S. Kobayashi, in "Catalysis in Precision Polymerization" $\mathrm{S}$ 
Kobayashi, Ed., John Wiley \& Sons Inc., Chichester, 1997, p 399.

2. (a) S. Kobayashi, C. Merlesdorf, T. Tanabe, K. Matsuo, and T. Saegusa, Polvm. Prepr. Jpn., 35, 248 (1986). (b) R. C. Schulz, and E. Schwarzenbach, Makromol. Chem., Macromol. Symp., 13/14, 495 (1988).

3. S. Kobayashi, E. Masuda, S. Shoda, and Y. Shimano, Macromolecules, 22, 2878 (1989).

4. H. Uyama and S. Kobayashi, Macromolecules, 24, 614 (1991).

5. Y. Shimano, K. Sato, and S. Kobayashi, Polym. Prepr., Jpn., 41, 1947 (1992).

6. S. Kobayashi, H. Uyama, S. W. Lee, and Y. Matsumoto, J. Polym. Sci., Part A, Polym. Chem., 31, 3133 (1993).

7. S. Shoda, E. Masuda, M. Furukawa, and S. Kobayashi, J. Polym Sci., Part A, Polym. Chem., 30, 1489 (1992).

8. (a) G. O. Schulz and R. J. Milkovich, J. Polym. Sci., Polym. Chem. Ed., 22, 1633 (1984). (b) Y. Tsukahara, M. Tanaka, and Y. Yamashita, Polym. J., 19, 1121 (1987). (c) K. Ito, N. Usami, and Y. Yamashita, Macromolecules, 13, 216 (1980). (d) R. Asami and M. Takaki, Makromol. Chem., Suppl., 12, 163 (1985).

9. (a) K. Ito, H. Tsuchida, A. Hayashi, T. Kitano, E. Yamada, and T. Matsumoto, Polym. J., 17, 827 (1985). (b) M. Niwa, M Akahori, and S. Nishigawa, J. Macromol. Sci. Chem., A24, 1423 (1987). (c) M. Akashi, I. Kirihira, and N. Miyauchi, Angew. Makromol. Chem., 132, 81 (1985). (d) C. G. Cameron and M. S. Chisholm, Polymer, 26, 437 (1985). (e) K. Mühlbach, V. Percec, and J. H. Wang, J. Polym. Sci., Polym. Chem. Ed., 25, 2605 (1987). (f) Y. Nabeshima and T. Tsuruta, Makromol. Chem., 190, 1635 (1989).
10. (a) W. Radke and A. H. E. Müller, Makromol. Chem., Macromol. Symp., 4/55, 583 (1992). (b) M. F. Farona and J. P. Kennedy, Polym. Bull., 11, 359 (1984).

11. (a) J. R. Cho and H. Morawetz, Macromolecules, 6, 628 (1973). (b) H. Morawetz, J. R. Cho, and P. J. Gans, Macromolecules, 6, 625 (1973).

12. (a) M. Niwa and N. Hayashi, Macromolecules, 21, 1193 (1988). (b) V. Percec and J. H. Wang, J. Polym. Sci., Part A: Polym. Chem., 28, 105 (1990). (c) M. Riza, S. Tokura, A. Kishida, and M. Akashi, New Polymeric Mater., 4, 189 (1994).

13. T. Miyake and S. Tanimoto, Yuki Gosei Kagaku Kyokaishi, 30, 1489 (1992).

14. Y. Shimano, K. Sato, and S. Kobayashi, Polym. J., in press.

15. F. R. Mayo and F. M. Lewis, J. Am. Chem. Soc., 66, 1954 (1944).

16. G. F. Meijs and E. Rizzardo, JMS-Rev. Macromol. Chem. Phys., C30, 305 (1990).

17. H. Fujihara, K. Yamazaki, Y. Matsubara, M. Yoshihara, and T. Maeshima, J. Macromol. Sci. Chem., A13, 1081 (1979).

18. (a) S. Lüsse and K. Arnold, Macromolecules, 29, 4251 (1996). (b) S. Ahuja, S. L. Dieckman, N. Gopalsami, and A. C. Raptis, Macromolecules, 29, 5356 (1996).

19. H. Keskkula and D. R. Paul, J. Appl. Polym. Sci., 31, 1189 (1986).

20. J. Lebduska, J. Snuparek, and K. Kaspar, Chem. Prum., 36, 472 (1986).

21. H. J. Harwood, Makromol. Chem., Macromol. Symp., 10/11, 331 (1987). 